\title{
Patterns of acoustic and morphometric variation in species of genus Tettigettalna (Hemiptera: Cicadidae): Sympatric populations show unexpected differences
}

\author{
Raquel MENDES, Vera L. NUNES, José A. QUARTAU and Paula C. SimÕES \\ Computational Biology and Population Genomics Group, Centro de Biologia Ambiental, DBA/FCUL, 1749-016 Lisboa, Portugal; \\ e-mails: raquelgmendes@gmail.com; vlnunes@fc.ul.pt; jaquartau@fc.ul.pt; pcsimoes@fc.ul.pt
}

Key words. Hemiptera, Cicadidae, Tettigettalna, acoustic signals, morphometry, sympatry

\begin{abstract}
Tettigettalna (Hemiptera: Cicadidae) is a genus of small sized cicadas occurring in south-western Europe, which consists of a complex of sibling species that are morphologically difficult to distinguish from each other but their calling songs can be used as the main character for their identification. These sibling species may sometimes occur in sympatry, therefore, this genus is a suitable model for addressing questions on isolation mechanisms and recognition processes. For this study, we selected T. argentata (the species with the broadest distribution) and the three other species of Tettigettalna (T. mariae, T. estrellae and T. josei) that are known to occur in sympatry with $T$. argentata at some locations in their distribution ranges. Thus, the present study investigates calling song and variation in external morphology in selected sympatric and allopatric populations of four species of Tettigettalna in order to determine whether there are patterns in population divergence that provide evidence of species recognition and reproductive isolation. The interspecific analysis of the calling songs showed that most time domain variables are species-specific although an overlap was found between the maximum and minimum values in T. argentata and T. mariae populations for four time domain variables. When only sympatric populations of $T$. argentata and $T$. mariae are compared, time domain variables show less variation leading to a reduced overlap between this pair of sibling species. The morphometric variables showed low interspecific variability and did not allow a complete separation of the four species, both in allopatric and sympatric populations. Sympatric populations of both T. argentata and T. mariae showed lower frequencies and bigger general body sizes than the allopatric ones. The pattern of variation found does not correspond to the pattern expected in species undergoing character displacement.
\end{abstract}

\section{INTRODUCTION}

Cicadas (Hemiptera: Cicadidae) constitute a group of insects generally known for the loud airborne acoustic signals produced by males. Male cicadas produce different types of acoustic signals, each with a particular function; the calling song is the most common with the primary function of female attraction and therefore plays a leading role in species recognition and pair formation (Cooley \& Marshall, 2001; Boulard, 2006). As a result, the structure of the calling song may function as a premating isolation mechanism in these species, in accordance with the biological species concept (Dobzhansky, 1937; Mayr, 1963); or be a part of the specific-mate recognition system (SMRS), according to the species recognition concept and should be subject to stabilizing selection and remain relatively constant across the distribution range of the species (Paterson, 1985).

In gregarious species, the calling song is also used to attract conspecific males in dense aggregations, where they produce a chorus (Alexander, 1968). There are several studies on the structure of the choruses of orthopterans (e.g. Snedden et al., 1998; Greenfield \& Snedden, 2002) but few on those of cicadas (e.g. Sueur \& Aubin, 2002; Sueur, 2003).

Tettigettalna is a genus of small sized cicadas from south-western Europe that occur in typical Mediterranean landscapes. This genus constitutes a complex of sibling species with very similar morphology, making most spe- cies indistinguishable from each other, and in which the calling songs can be used as the main character for their identification. The genus has recently been revised to include nine species, which are with one exception, endemic to the Iberian Peninsula (Sueur et al., 2004; Puissant \& Sueur, 2010). Tettigettalna argentata (Olivier, 1790) is the species with the widest distribution, occurring mostly on the Iberian and Italian peninsulas and in the south of France (D’Urso, 1995; Sueur et al., 2004; Puissant \& Sueur, 2010), with a north-eastern distribution reaching southern Switzerland (Hertach, 2008) and the westernmost part of Slovenia (Schedl, 1986; Gogala \& Gogala, 1999; Gogala, 2002).

Previous studies documented the occurrence of $T$. argentata populations in sympatry with three other species of Tettigettalna (Boulard, 1982; Quartau \& Boulard, 1995; Sueur et al., 2004): Tettigettalna estrellae (Boulard, 1982), which is restricted to the northwest of Portugal and Tettigettalna mariae (Quartau \& Boulard, 1995) and Tettigettalna josei (Boulard, 1982), both restricted to the south-western region of the Iberian Peninsula. Similarly T. mariae and $T$. josei may also be found in sympatry in Algarve.

A recent DNA barcode study (Nunes et al., 2014) reveals that $T$. argentata is geographically structured in two clades, North and South. T. mariae in frequent sympatry with T. argentata in the south, diverges very little from the southern clade of T. argentata and shares with it its most common haplotype. It is unclear whether the sharing of haplotypes is due to introgression or incomplete lineage sorting. Pairs 
of closely related cicadas occurring either in sympatry or allopatry provide important case studies for investigating the microevolutionary processes involved in speciation and recognition (Marshall \& Cooley, 2000; Quartau \& Simões, 2006; Seabra et al., 2006). When the distribution of two closely related species overlaps, a divergence in the sympatric populations can be expected. This character displacement may reinforce the isolation mechanism and thus reduce the possibilities of hetero-specific mating (reproductive character displacement; Dobzhansky, 1937); reduce interspecific exploitative competition for resources (ecological character displacement; Adams \& Rohlf, 2000) or even reduce interspecific interference competition (agonistic character displacement, Grether et al., 2009). Paterson (1985) on the other hand argued that reinforcement does not occur, since in his Species Recognition Concept species are seen as "that most inclusive population of individual biparental organisms which share a common fertilization system" (or Specific-Mate Recognition System SMRS). According to this author, if two populations show heterozygote disadvantage but share a common SMRS, natural selection will act to eliminate the cause of hybrid disadvantage and consequently these two populations cannot coexist and reproductive character displacement is not expected.

Tettigettalna species are an ideal model to study the above mentioned microevolutionary processes. Hence, we analyzed the variation in acoustic signals and morphology of four species of Tettigettalna (T. argentata, T. estrellae, T. mariae and T. josei). Following this analysis we selected the most closely related pair of species that occur both in sympatry and allopatry in order to determine whether population divergence occurs in sympatry and better understand species recognition and reproductive isolation.

\section{METHODS}

\section{Sampling methodology}

Males of the Tettigettalna species were collected and their calling songs recorded during the summers of 2011 and 2012. Fieldwork took place mostly in the west and south of the Iberian Peninsula, where the selected species are known to occur (Sueur et al., 2004) and in order to find and sample both allopatric and sympatric populations. The sampling effort was most intense in the Algarve (south of Portugal) where the chances of finding populations of $T$. argentata in sympatry with other Tettigettalna species (either T. mariae or T. josei) were higher (Table 1, Fig. 1). Males were first located by their calling songs and their songs recorded in the field prior to collecting them by hand or sweep net. Recordings of male calling songs were made using a Sony DAT TCD-D10 Pro II digital audiotape recorder (frequency response $20 \mathrm{~Hz}-22 \mathrm{kHz}$; sampling frequency $44.1 \mathrm{kHz}$ ) with a Sony F-780 dynamic microphone $(50 \mathrm{~Hz}-18 \mathrm{kHz})$, or a Marantz PMD 661 Portable SD Recorder (frequency response $20 \mathrm{~Hz}-$ $24 \mathrm{kHz}$; sampling frequency $96 \mathrm{kHz}$ ) with a Telinga Microphone - PRO7, DATmic Twin Science microphone $(60 \mathrm{~Hz}-18 \mathrm{kHz})$. Ambient temperature was measured in the shade at the time and place of each recording. Male calling songs were recorded with temperature within the range of $24^{\circ} \mathrm{C}$ to $39^{\circ} \mathrm{C}$.

TABLE 1. Allopatric and sympatric populations of the four species of Tettigettalna sampled with the number of specimens recorded/ captured at each location. Grey cells - allopatric populations; white cells - sympatric populations of the four species of Tettigettalna. * - localities with a triple sympatry (T. argentata, T. mariae and T. josei).

\begin{tabular}{|c|c|c|c|c|}
\hline \multirow{2}{*}{$\begin{array}{l}\text { Sympatric } \\
\text { with }\end{array}$} & \multicolumn{4}{|c|}{ Collected specimens (recorded/captured) } \\
\hline & T. argentata & T. mariae & T. estrellae & T. josei \\
\hline T. argentata & $\begin{array}{c}\text { Ayamonte }(0 / 1) \\
\text { Cartaya }(1 / 0) \\
\text { Castelo de Vide }(6 / 6) \\
\text { Espiel }(1 / 6) \\
\text { Évora }(1 / 0) \\
\text { Huelva }(1 / 0) \\
\text { Monforte da Beira }(3 / 0) \\
\text { Portel }(13 / 10) \\
\text { Serra d'Aire }(4 / 4) \\
\text { Sesimbra }(13 / 11) \\
\text { Vale de Água }(8 / 6) \\
\text { Verdelhos }(2 / 0) \\
\text { Villablanca }(1 / 6)\end{array}$ & $\begin{array}{c}\text { Quinta do Lago }(10 / 11) * \\
\text { Vale Verde }(2 / 0)\end{array}$ & $\begin{array}{c}\text { Braga }(10 / 15) \\
\text { Serra da Estrela (4/1) }\end{array}$ & $\begin{array}{c}\text { Moncarapacho (3/3) } \\
\text { Quinta do Lago }(6 / 11) * \\
\text { São Brás de Alportel (1) } \\
\text { Vila do Bispo }(0 / 1)\end{array}$ \\
\hline T. mariae & $\begin{array}{l}\text { Quinta do Lago }(14 / 11) * \\
\text { Vale do Lobo }(1 / 0) \\
\text { Vale Verde }(1 / 0)\end{array}$ & $\begin{array}{c}\text { Cartaya }(6 / 1) \\
\text { Corgo da Zorra }(4 / 1) \\
\text { Huelva }(3 / 0) \\
\text { Vale do Lobo }(11 / 6) \\
\text { Vale Judeu }(14 / 10) \\
\end{array}$ & & \\
\hline T. estrellae & $\begin{array}{c}\text { Braga }(5 / 3) \\
\text { Serra da Estrela }(4 / 1)\end{array}$ & & Baião (5/8) & \\
\hline T. josei & $\begin{array}{c}\text { Moncarapacho (1/1) } \\
\text { São Bartolomeu de Messines (9/9) } \\
\text { São Brás de Alportel }(1 / 0) \\
\text { Vila do Bispo }(1 / 1)\end{array}$ & & & $\begin{array}{c}\text { Bugens }(0 / 3) \\
\text { Castro Marim }(2 / 6) \\
\text { Lagoa }(11 / 12) \\
\text { Tavira }(0 / 1) \\
\text { Vale Judeu }(10 / 9)\end{array}$ \\
\hline Total & $91 / 76$ & $50 / 29$ & $19 / 24$ & $33 / 47$ \\
\hline
\end{tabular}




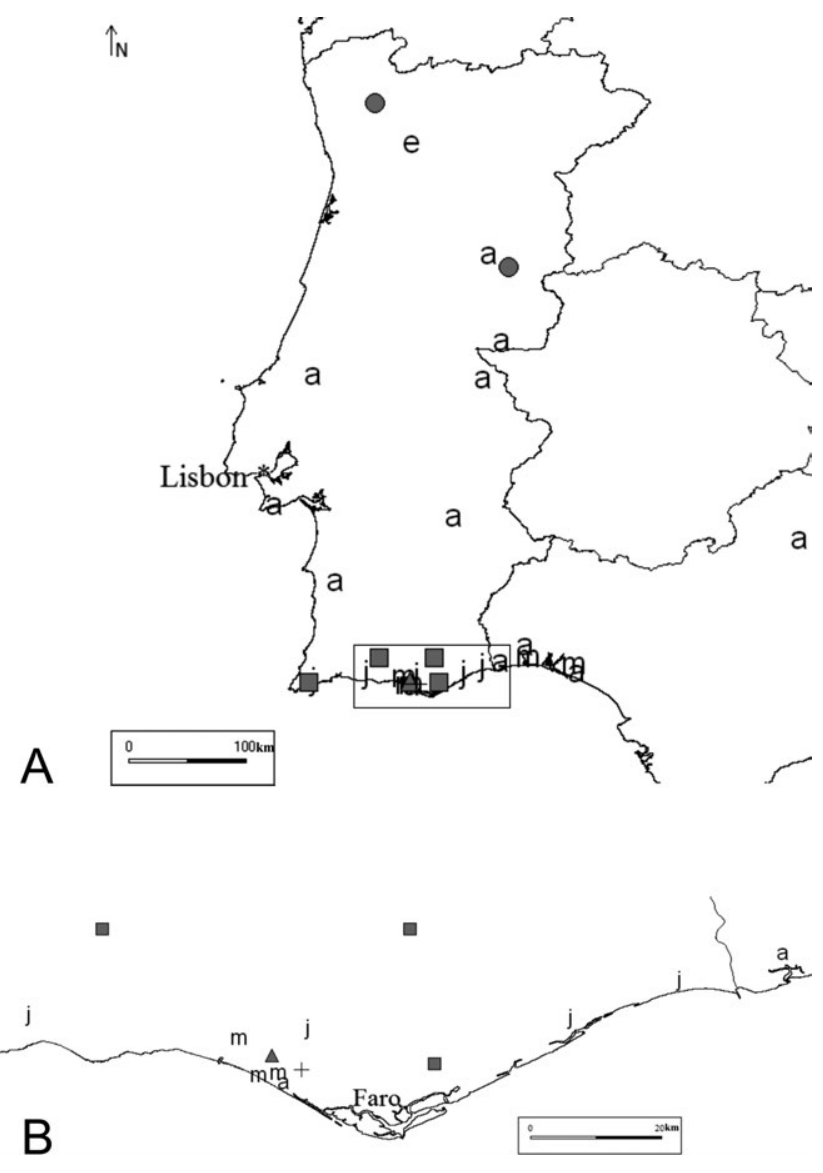

The distribution status (sympatry or allopatry) of each population was determined acoustically. A population of a species was considered allopatric with another species when no other Tettigettalna species could be heard calling in their surroundings
Fig. 1. A - Map of the south-western part of the Iberian Peninsula showing the locations of the allopatric and sympatric populations of the four species of Tettigettalna sampled. B - More detailed map of the area marked by the rectangle in A. Letters: allopatric populations of: $\mathrm{a}-T$. argentata; $\mathrm{e}-T$. estrellae; $\mathrm{j}-$ T. josei and $\mathrm{m}-$ T. mariae. Symbols: Sympatric populations of: circle - T. argentata and T. estrellae; square - T. argentata and $T$. josei; triangle: T. argentata and T. mariae and cross: T. argentata, T. mariae and T. josei. Map produced by the program DIVA_GIS (LizardTechSeattle, USA) using the spatial data provided by this program.

and sympatric, when more than one species could be heard at the same location. GPS coordinates of all sampling sites were registered with a Garmin Oregon 550t.

Acoustic recordings and specimens are deposited in the general data bank on insect data at the Department of Animal Biology in the Faculty of Sciences, University of Lisbon (FCUL).

\section{Acoustic analysis}

Acoustic recordings were analyzed with Avisoft-SASLab Pro software (Specht, 2012) with a sampling rate of $44.1 \mathrm{kHz}$ and a resolution of 16 bits. Spectra were computed using FFT with a resolution of 512 points and a Hamming Window. Both time and frequency domains were analyzed. The time variables considered in the analyses were: number (A) and duration (B) of echemes, and duration of the inter-echeme interval $(C)$. Echeme periods (D) and echeme/interval ratio (E) were then calculated. Spectrum-based variables analyzed were: peak frequency $(\mathrm{F})$, minimum frequency $(\mathrm{G})$, maximum frequency $(\mathrm{H})$, band widths $(\mathrm{I})$ and quartiles (J-M) (see Pinto-Juma et al., 2005 for description of variables). Letters within brackets correspond to the variable code assigned to the respective variable.

For each specimen and whenever possible at least $30 \mathrm{~s}$ of the calling song were analyzed. All frequency measurements were calculated from the mean spectrum of each echeme. Time and

TABLE 2. List and description of the 22 traits of the external morphology of the four species of Tettigettalna measured for the morphometric analysis along with their codes and abbreviations (Abbrev.).

\begin{tabular}{|c|c|c|c|}
\hline $\begin{array}{l}\text { Body } \\
\text { region }\end{array}$ & $\begin{array}{l}\text { Variable } \\
\text { code }\end{array}$ & Abbrev. & Description \\
\hline \multirow{8}{*}{$\begin{array}{l}\text { Head and } \\
\text { thorax }\end{array}$} & 1 & BL & Body length measured from tip of the head to the end of the wings in resting position \\
\hline & 2 & HL & Front length measured along the dorsal median line \\
\hline & 3 & PL & Pronotum length measured along the dorsal median line \\
\hline & 4 & ML & Mesonotum length measured along the dorsal median line \\
\hline & 5 & HW & Head width measured between exterior eye margins \\
\hline & 6 & ID & Smaller inter-ocular distance \\
\hline & 7 & OOD & Greatest distance between the two dorsal ocelli \\
\hline & 9 & $\mathrm{CL}$ & Postclypeus length measured along the median line \\
\hline \multirow{4}{*}{ Abdomen } & 8 & TTD & Distance between the two tymbals in dorsal view \\
\hline & 12 & OW & Operculum width in ventrolateral view \\
\hline & 13 & $\mathrm{TL}$ & Tymbal length \\
\hline & 22 & nTR & Number of tymbal ribs \\
\hline \multirow{2}{*}{ Legs } & 10 & FL & Femur length measured along the median line \\
\hline & 11 & $\mathrm{fFL}$ & Maximum length of the femur's $1^{\text {st }}$ thorn \\
\hline \multirow{8}{*}{ Wings } & 14 & aWL & Forewing length measured from base of the forewing articulation to the tip of wing \\
\hline & 15 & aWW & Maximum forewing width \\
\hline & 16 & BCL & Maximum length of the forewing basal cell \\
\hline & 17 & RCL & Maximum length of the forewing radial cell \\
\hline & 18 & PCL & Maximum length of the forewing poscostal cell \\
\hline & 19 & $\mathrm{M}+\mathrm{Cu} 1 \mathrm{~L}$ & Maximum length of the common branch between the media and the $1^{\text {st }}$ cubitus cell of the forewing \\
\hline & 20 & pWL & Hind wing length measured from the articulation to tip of the wing \\
\hline & 21 & pWW & Maximum hind wing width \\
\hline
\end{tabular}




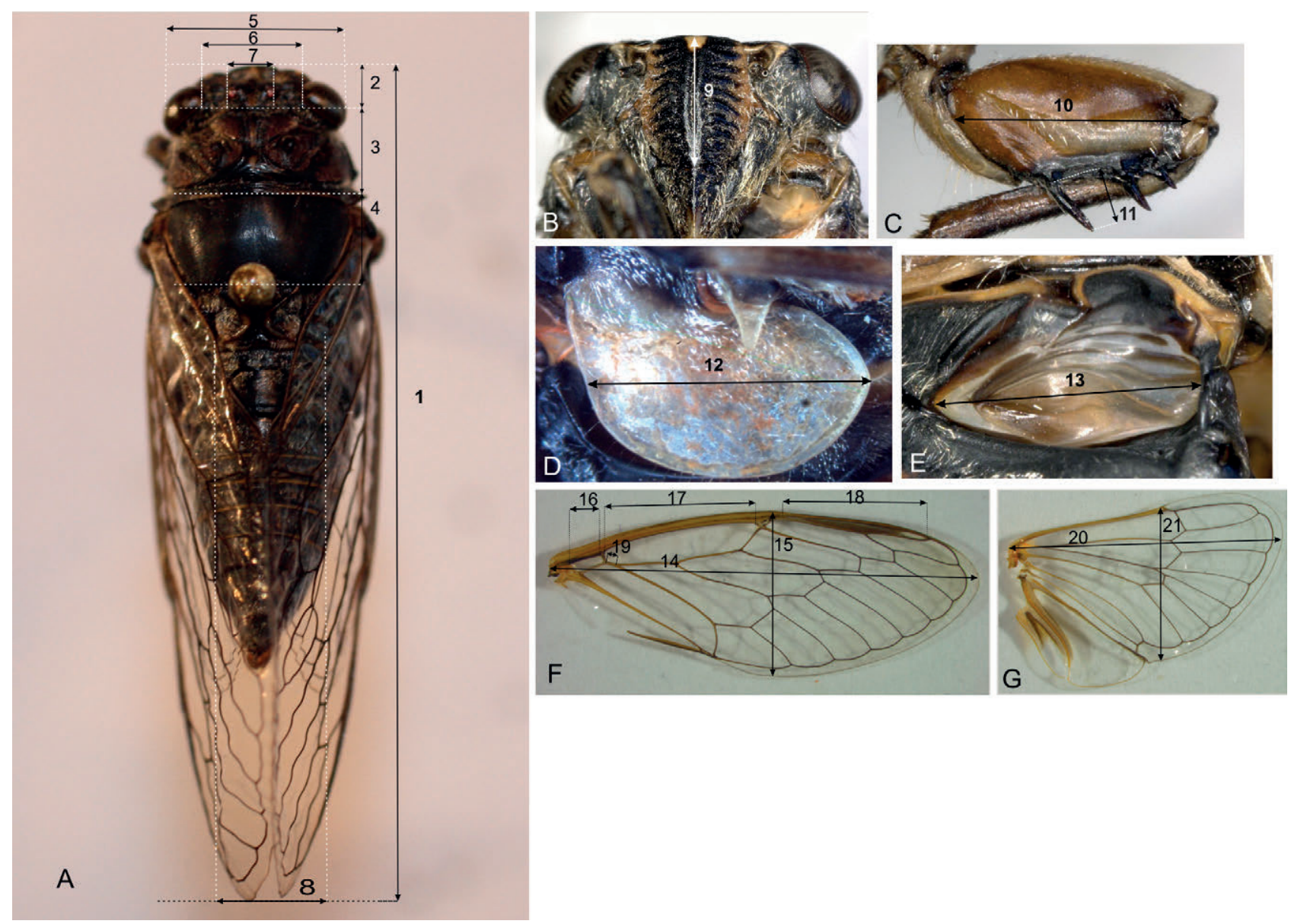

Fig. 2. The traits of external morphology of specimens of Tettigettalna measured. A - dorsal view; B - ventral view of the head; C anterior femur; D - operculum; E - tymbal; F - anterior wing; G - posterior wing. (See Table 2 for detailed description).

frequency measurements were averaged and the mean was taken as the value of the variable for each specimen.

\section{Morphometric analysis}

Morphometric analyses of dry pinned specimens were performed under a Wild Heerbrugg binocular microscope fitted with an ocular micrometer $(10 \times)$. A total of 22 traits of external morphological structures of the head and thorax including wings, legs and tymbals as shown in Fig. 2 were measured and are described in Table 2. Except for damaged specimens all measurements were made on the right side of each specimen. The measurements consisted of two independent series. In each series, all traits were measured once for each specimen. The values for each trait for a specimen were averaged between the two series, and the mean was taken as the value of the trait variable for the specimen.

\section{Statistical analysis}

Statistical tests were performed using STATISTICA 11.0 (StatSoft, Tulsa, USA). The acoustic and morphometric analysis generated two data matrices of 13 and 22 variables, respectively. These matrices were separately analyzed using several statistical procedures. Descriptive statistics of each acoustic and morphometric variable for each species was calculated. A normality test revealed that variables in both matrices were not normally distributed and as such, comparative statistics were performed using nonparametric tests.

A Spearman nonparametric correlation between ambient temperature and each acoustic variable were calculated for each species. No correlation was found, and as such no data correction was necessary.
Nonparametric Kruskal-Wallis (KW) test were used to compare each acoustic and morphometric variable between species. In order to reduce the variables to a small number of components, as well as to assess the correlation between the variables and those components (component loadings) a multivariate Principal Component Analysis (PCA) was applied to the correlation matrix of the 13 acoustic variables as well as to the correlation matrix of 22 morphometric variables. The Kaiser criterion was used to determine the components with eigenvalues greater than one. Kruskal-Wallis tests were then used to compare the component scores obtained for the individuals between species. These analyses allowed the identification of the pairs of species that were more closely related, which were then analyzed at the population level. The Mann-Whitney (MW) test was used to compare the morphometric and acoustic variables between sympatric and allopatric populations of each species.

The significance of all multiple tests was assessed by reducing the critical $\mathrm{P}$ value according to the Dunn-Sidák method (Dytham, 2011), from 0.05 to $1-(0.95)^{1 / k}$, where $\mathrm{k}$ is the number of tests performed.

\section{RESULTS}

Fieldwork during the summers of 2011 and 2012 resulted in a total of 193 acoustic recordings and the capture of 176 specimens that were used in the morphometric analysis (Table 1). We sampled T. argentata at 22 locations, mostly in the west of the Iberian Peninsula. This species occurred 
TABle 3. Descriptive statistics of the acoustic variables analyzed for the four species of Tettigettalna. Time is in seconds and frequency in kHz. N - number of specimens of each species recorded; Min-Max - minimum-maximum range; SD - standard deviation.

\begin{tabular}{|c|c|c|c|c|c|c|c|c|c|}
\hline \multirow{2}{*}{$\begin{array}{l}\text { Var. } \\
\text { code }\end{array}$} & \multirow{2}{*}{ Variable name } & \multicolumn{2}{|c|}{ T. argentata $(\mathrm{N}=91)$} & \multicolumn{2}{|c|}{ T. mariae $(\mathrm{N}=50)$} & \multicolumn{2}{|c|}{ T. estrellae $(\mathrm{N}=19)$} & \multicolumn{2}{|c|}{ T. josei $(\mathrm{N}=33)$} \\
\hline & & Mean \pm SD & Min-Max & Mean \pm SD & Min-Max & Mean \pm SD & Min-Max & Mean \pm SD & Min-Max \\
\hline A & No. of echemes/s & $12.829 \pm 1.485$ & $9.797-16.976$ & $3.827 \pm 1.565$ & $1.863-8.980$ & $5.903 \pm 2.848$ & $0.361-8.333$ & $45.156 \pm 3.667$ & $36.732-51.094$ \\
\hline B & Echeme duration & $0.016 \pm 0.005$ & $0.007-0.030$ & $0.058 \pm 0.023$ & $0.020-0.112$ & $3.461 \pm 1.370$ & $0.699-4.861$ & $0.007 \pm 0.002$ & $0.005-0.013$ \\
\hline $\mathrm{C}$ & Inter-echeme interval & $0.071 \pm 0.013$ & $0.041-0.097$ & $0.263 \pm 0.094$ & $0.089-0.528$ & $4.838 \pm 2.018$ & $0.600-6.815$ & $0.023 \pm 0.007$ & $0.017-0.050$ \\
\hline $\mathrm{D}$ & Echeme period & $0.086 \pm 0.012$ & $0.063-0.116$ & $0.321 \pm 0.111$ & $0.114-0.572$ & $8.300 \pm 3.369$ & $1.284-11.676$ & $0.030 \pm 0.007$ & $0.022-0.056$ \\
\hline $\mathrm{E}$ & $\begin{array}{l}\text { Echeme/inter-echeme } \\
\text { interval ratio }\end{array}$ & $0.246 \pm 0.123$ & $0.122-0.720$ & $0.245 \pm 0.080$ & $0.084-0.466$ & $1.106 \pm 0.921$ & 0.566 & $0.330 \pm 0.092$ & 0.613 \\
\hline $\mathrm{F}$ & Peak frequency & $11.78 \pm 2.16$ & $6.62-14.01$ & $11.55 \pm 1.97$ & $6.52-13.73$ & $12.82 \pm 0.91$ & $10.56-14.13$ & $15.82 \pm 0.25$ & $14.76-16.17$ \\
\hline G & Minimum frequency & $5.66 \pm 0.69$ & $4.80-6.93$ & $5.48 \pm 0.60$ & $4.30-7.74$ & $6.77 \pm 0.99$ & $4.80-8.62$ & $8.60 \pm 1.04$ & $5.45-9.77$ \\
\hline $\mathrm{H}$ & Maximum frequency & $16.73 \pm 0.84$ & $14.45-18.05$ & $16.69 \pm 0.56$ & $14.84-17.74$ & $16.47 \pm 0.40$ & $15.63-17.42$ & $19.29 \pm 1.10$ & $18.02-22.73$ \\
\hline I & Bandwidth & $11.04 \pm 0.87$ & $9.48-13.14$ & $1.117 \pm 0.70$ & $9.25-12.86$ & $9.68 \pm 0.96$ & $8.45-12.52$ & $10.69 \pm 1.84$ & $8.91-16.03$ \\
\hline $\mathrm{J}$ & 25\%Quartile & $9.34 \pm 1.30$ & $6.84-11.67$ & $9.33 \pm 1.25$ & $6.81-11.01$ & $10.42 \pm 1.06$ & $8.48-12.36$ & $12.74 \pm 0.56$ & $11.26-13.54$ \\
\hline K & $50 \%$ Quartile & $11.93 \pm 1.06$ & $9.57-13.51$ & $11.92 \pm 0.73$ & $10.05-13.20$ & $12.43 \pm 0.80$ & $10.77-13.78$ & $15.19 \pm 0.37$ & $13.95-16.05$ \\
\hline $\mathrm{L}$ & 75\% Quartile & $13.68 \pm 0.82$ & $11.55-14.91$ & $13.64 \pm 0.66$ & $11.79-16.41$ & $13.65 \pm 0.55$ & $12.66-14.87$ & $16.60 \pm 0.59$ & $15.91-18.29$ \\
\hline M & $75 \%-25 \%$ Quartile & $4.34 \pm 0.84$ & $2.67-6.51$ & $4.31 \pm 1.22$ & $2.65-9.60$ & $3.23 \pm 0.65$ & $2.47-4.87$ & $3.86 \pm 0.87$ & $2.78-6.25$ \\
\hline
\end{tabular}

frequently in sympatry with $T$. mariae and $T$. josei in the Algarve and rarely with T. estrellae (Fig. 1A, B).

\section{Interspecific acoustic analysis}

Descriptive statistics of the acoustic variables analyzed for all four species studied are shown in Table 3. In relation to the time domain and except for the echeme/inter-echeme interval, all variables were significantly different between T. argentata and T. mariae (Table 4; KW, $\mathrm{p}<0.0042$ ). However, with the exception of the number of echemes/s, there is an overlap between the minimum and maximum values in all the time domain variables of these species (Table 3). Tettigettalna josei is statistically significantly different from the remaining three species (Table 3 and 4). Tettigettalna estrellae has the lowest number of echemes/s and longest duration of echemes, inter-echeme interval and echeme period. Nonetheless, values of these four variables for $T$. estrellae are statistically similar to those of T. mari$a e$. The values of all the time variables of T. estrellae and $T$. argentata are statistically significantly different (Table 4).

In the frequency domain, $T$. jose $i$ is significantly different from the other species in all but three variables (Table $4 ; \mathrm{KW}, \mathrm{p}<0.0042)$. All the variables of the frequency domain of Tettigettalna argentata and T. mariae are very similar (Table 4; KW, p>0.0042), but the average values for $T$. argentata are in general slightly higher than those of T. mariae (Table 3). Tettigettalna estrellae is similar to these two species, only differing significantly in three variables (Table 4; KW, $\mathrm{p}<0.0042$ ).

Interspecific differences in acoustic variables were not significantly correlated with the temperature at which they were recorded for any of the species studied (Spearman Correlation Rank with Dunn-Sidák correction of the $P$ value $=0.0039)$.

The percentage of variation explained by the three extracted principal components was 90.84\% (Supplementary Table, ST1). A complete separation between the four species is not evident (Fig. 3). The most detached species is $T$. josei with specimens homogeneously grouping in the $1^{\text {st }}$ quadrant. Tettigettalna estrellae occupies mainly the $3^{\text {rd }}$ quadrant of the scatter plot, while T. argentata and $T$. mariae group together in the $2^{\text {nd }}$ quadrant. Therefore, the latter two species constitute a more homogeneous group with many specimens difficult to distinguish from each other (Fig. 3). KW nonparametric analysis shows that there are no differences between them in any of the three components extracted (KW, $\mathrm{p}>0.0042)$.

\section{Interspecific morphometric analysis}

The descriptive statistics of the morphometric traits measured is shown in Table 5. Due to its smaller size, $T$. josei is the most dissimilar species (Table 4 and 5) and the only one that can be separated based on morphology alone. Tettigettalna argentata and T. mariae did not differ significantly in any of these morphometric traits (Table $4 ; \mathrm{KW}$, $\mathrm{p}>0.0042)$. However, T. mariae specimens were in general larger than T. argentata. Tettigettalna estrellae is similar to these two species only differing significantly from each of them in two morphometric traits (Table 4).

The percentage of variation explained by the two extracted principal components was $74.27 \%$ (ST2). As expected the most different species is $T$. josei, which is on the left

TABLE 4. Acoustic (upper diagonal) and morphometric traits (lower diagonal) with statistical differences between each pair of species, based on a Kruskal-Wallis test (Critical P value $=0.0042$ ). Each number corresponds to a morphometric trait as shown in Table 2 and each letter corresponds to an acoustic variable as shown in Table 3.

\begin{tabular}{lcccc}
\hline & T. argentata & T. mariae & T. estrellae & T. josei \\
\hline T. argentata & & ABCD & ABCDEGIM & ABCDEFGHJKL \\
T. mariae & - & & EGIM & ABCDFGHIJKL \\
T. estrellae & $9 ; 17$ & $7 ; 11$ & & ABCDEFHJKL \\
T. josei & $1-11 ; 13-19 ; 21-22$ & $1-11 ; 13-19 ; 21-22$ & $1-6 ; 8 ; 9 ; 11 ; 13-19 ; 21-22$ & \\
\hline
\end{tabular}




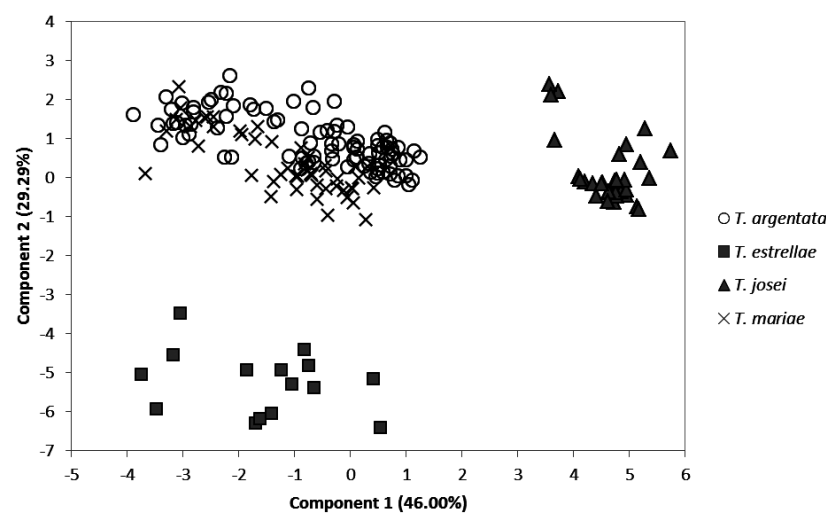

Fig. 3. Scatter plot of the 193 specimens of Tettigettalna in the first two PCA components extracted from a correlation matrix composed of 13 acoustic variables. See ST1 in Supplementary Tables for details of the Eigen analysis and factor loadings.

side of the scatter plot (Fig. 4), mostly due to its small size, while the remaining species overlap on the right side. KW nonparametric analysis revealed a significant difference between $T$. jose $i$ and all the other species in the $1^{\text {st }}$ component $(\mathrm{p}<0.0042)$.

The analysis of the interspecific variation in the acoustic and morphometric variables show that the closest pair of species is $T$. argentata and T. mariae. As they frequently occur in sympatry in the south of Portugal and are genetically similar (Nunes et al., 2014) they were further investigated at the population level.

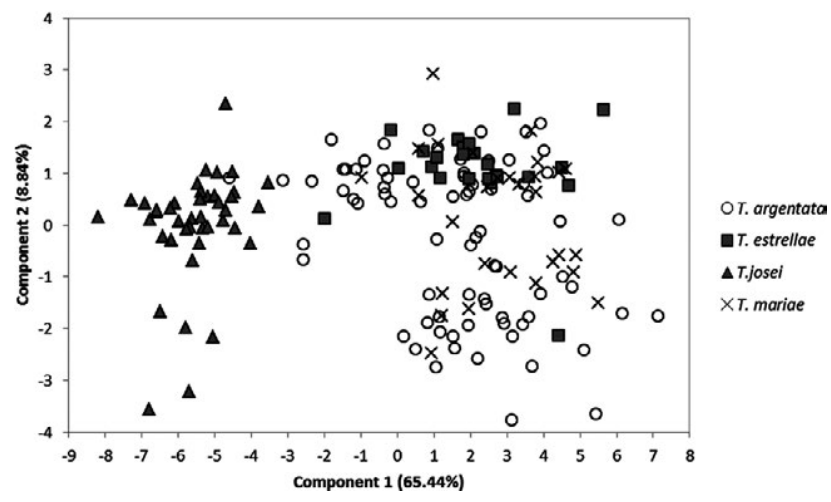

Fig. 4. Scatter plot of the 176 specimens of Tettigettalna in the two PCA components extracted from a correlation matrix composed of 22 morphometric traits. See ST2 for details of the Eigen analysis and factor loadings.

\section{Allopatric and sympatric populations of T. argentata and $T$. mariae}

The analysis of allopatric and sympatric populations of T. argentata and T. mariae was performed on a subset of the populations sampled in the Algarve, since the distribution of T. mariae is limited to this region. For the acoustic analysis 69 recordings of their calling songs (28 T. argentata and 41 T. mariae) were analyzed and 50 captured specimens (22 T. argentata and 28 T. mariae) were used for the morphometric analysis.

Acoustic analysis of the calling songs of individuals in sympatric populations of $T$. argentata revealed that they have fewer echemes/s, shorter inter-echeme intervals and echeme periods and longer echeme durations and echeme/

TABLE 5. Descriptive statistics (mean \pm standard deviation) of the morphometric traits of the four species of Tettigettalna species. $\mathrm{N}$ - number of specimens of each species measured. \#/\# Traits for which measurements of one/two specimens less then indicated (N) were included in the analysis.

\begin{tabular}{|c|c|c|c|c|c|}
\hline Body region & Variable & $\begin{array}{l}\text { T. argentata } \\
(\mathrm{N}=76)\end{array}$ & $\begin{array}{l}\text { T. mariae } \\
(\mathrm{N}=29)\end{array}$ & $\begin{array}{c}\text { T. estrellae } \\
(\mathrm{N}=24)\end{array}$ & $\begin{array}{c}\text { T. josei } \\
(\mathrm{N}=47)\end{array}$ \\
\hline \multirow{8}{*}{ Head and thorax } & $\mathrm{BL}(\mathrm{mm})$ & $23.33 \pm 1.54$ & $24.30 \pm 0.97$ & $23.73 \pm 1.16$ & $19.09 \pm 0.61$ \\
\hline & $\mathrm{HL}(\mathrm{mm})$ & $1.32 \pm 0.17$ & $1.37 \pm 0.18$ & $1.37 \pm 0.12$ & $1.18 \pm 0.15$ \\
\hline & PL (mm) & $2.40 \pm 0.18$ & $2.44 \pm 0.12$ & $2.52 \pm 0.10$ & $1.95 \pm 0.11$ \\
\hline & $\mathrm{ML}(\mathrm{mm})$ & $4.16 \pm 0.62$ & $4.16 \pm 0.32$ & $4.05 \pm 0.21$ & $3.24 \pm 0.23$ \\
\hline & HW (mm) & $5.24 \pm 0.29$ & $5.37 \pm 0.20$ & $5.24 \pm 0.21$ & $4.51 \pm 0.17$ \\
\hline & ID (mm) & $2.72 \pm 0.22$ & $2.79 \pm 0.13$ & $2.71 \pm 0.12$ & $2.30 \pm 0.09$ \\
\hline & OOD $(\mathrm{mm})$ & $1.29 \pm 0.11$ & $1.33 \pm 0.08$ & $1.23 \pm 0.06$ & $1.16 \pm 0.11$ \\
\hline & $\mathrm{CL}(\mathrm{mm})$ & $2.16 \pm 0.15$ & $2.26 \pm 0.10$ & $2.10 \pm 0.16$ & $1.91 \pm 0.11$ \\
\hline \multirow{4}{*}{ Abdomen } & TTD (mm) & $1.82 \pm 0.15^{\#}$ & $1.95 \pm 0.16$ & $2.02 \pm 0.17$ & $1.41 \pm 0.11$ \\
\hline & $\mathrm{OW}(\mathrm{mm})$ & $2.60 \pm 0.38$ & $2.66 \pm 0.40$ & $2.40 \pm 0.30$ & $2.24 \pm 0.25$ \\
\hline & $\mathrm{TL}(\mathrm{mm})$ & $2.52 \pm 0.16^{\#}$ & $2.63 \pm 0.11$ & $2.44 \pm 0.11$ & $1.96 \pm 0.07$ \\
\hline & $\mathrm{nTR}(\mathrm{n})$ & $4.95 \pm 0.22^{\# \#}$ & $5.03 \pm 0.27$ & $4.98 \pm 0.10$ & $4.96 \pm 0.23$ \\
\hline \multirow{2}{*}{ Legs } & $\mathrm{FL}(\mathrm{mm})$ & $2.69 \pm 0.18$ & $2.73 \pm 0.13$ & $2.76 \pm 0.11$ & $2.12 \pm 0.09^{\#}$ \\
\hline & fTL (n) & $0.72 \pm 0.11$ & $0.72 \pm 0.10$ & $0.78 \pm 0.10$ & $0.53 \pm 0.07$ \\
\hline \multirow{8}{*}{ Wings } & $\mathrm{aWL}(\mathrm{mm})$ & $19.37 \pm 1.38$ & $19.98 \pm 0.80$ & $19.52 \pm 0.80$ & $15.62 \pm 0.59$ \\
\hline & aWW (mm) & $7.28 \pm 0.51$ & $7.38 \pm 0.43$ & $7.51 \pm 0.37$ & $6.20 \pm 0.50$ \\
\hline & $\mathrm{BCL}(\mathrm{mm})$ & $1.71 \pm 0.16$ & $1.80 \pm 0.15$ & $1.89 \pm 0.13$ & $1.51 \pm 0.14$ \\
\hline & RCL (mm) & $7.13 \pm 0.46$ & $7.26 \pm 0.27$ & $7.15 \pm 0.44$ & $5.87 \pm 0.23$ \\
\hline & PCL (mm) & $6.50 \pm 0.48^{\#}$ & $6.78 \pm 0.42$ & $6.88 \pm 0.46$ & $5.43 \pm 0.31$ \\
\hline & $\mathrm{M}+\mathrm{Cu} 1 \mathrm{~L}(\mathrm{~mm})$ & $0.99 \pm 0.28$ & $0.96 \pm 0.28$ & $0.94 \pm 0.33$ & $0.73 \pm 0.16$ \\
\hline & pWL (mm) & $10.93 \pm 0.70$ & $11.26 \pm 0.48$ & $11.26 \pm 0.60$ & $8.84 \pm 0.35$ \\
\hline & $\mathrm{pWW}(\mathrm{mm})$ & $5.87 \pm 0.62$ & $5.83 \pm 0.54$ & $5.69 \pm 0.37$ & $4.62 \pm 0.27$ \\
\hline
\end{tabular}



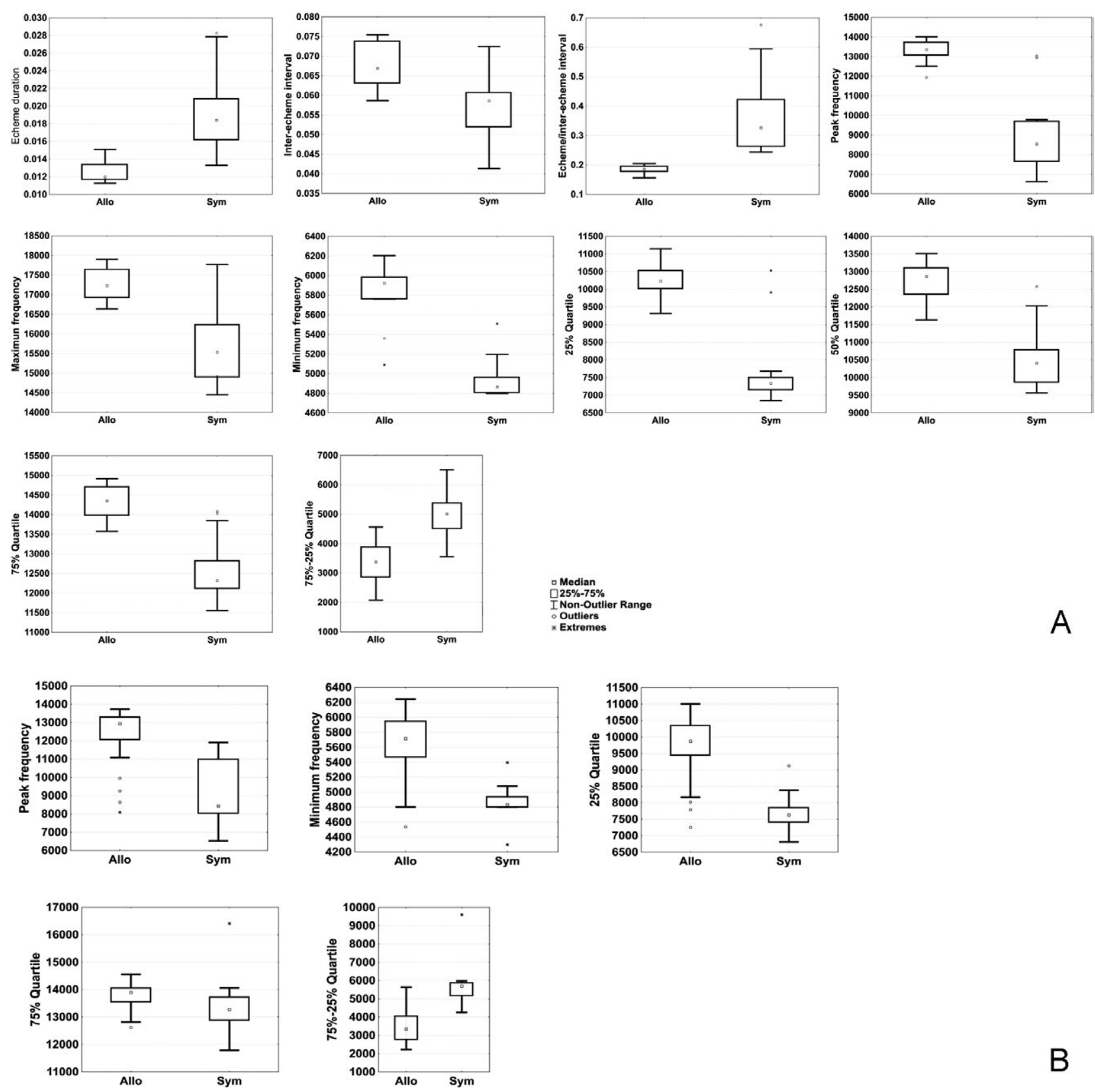

Fig. 5. Box plot of the acoustic variables that differed statistically (Mann-Whitney, $\mathrm{p}<0.0039$ ) between allopatric (Allo) and sympatric (Sym) populations of A - Tettigettalna argentata and B - Tettigettalna mariae. Time is in seconds and frequency in $\mathrm{kHz}$.

inter-echeme intervals than their allopatric conspecifics. In all but one variable these differences were significant (Fig. $5 \mathrm{~A} ; \mathrm{MW}, \mathrm{p}<0.0039)$. In respect to the frequency domain there is a decrease in all variables other than the $75 \%$ Quartile - 25\% Quartile average frequency, which is lower in the sympatric populations. Once again, and with the exception of the band width, all differences were significant (Fig. 5A; MW, p <0.0039).

In contrast, no significant differences were found in the time variables of $T$. mariae populations (MW, $\mathrm{p}>0.0039$ ) even though there are fewer echemes/s, shorter interecheme intervals and longer echeme durations, echeme periods and echeme/inter-echeme interval ratio in the recording for sympatric populations. However, in the frequency domain, sympatric populations of $T$. mariae have lower frequency values in all variables except for the increase in the 75\% Quartile - 25\% Quartile average frequency. Among these differences only the peak and minimum frequency; the $25 \%$ and $75 \%$ quartile and the $75 \%$ Quartile $-25 \%$ Quartile are statistically different (Fig. 5B; MW, $\mathrm{p}<0.0039$ ).

When only sympatric populations were analyzed, only the values for echeme duration and inter-echeme interval overlapped.

A total of three components where extracted by PCA, which account for $86.91 \%$ of the variation (ST3). The two species are separated by component 2 , with $T$. mariae distributed above $T$. argentata in the scatter plot (Fig. 6). KW 


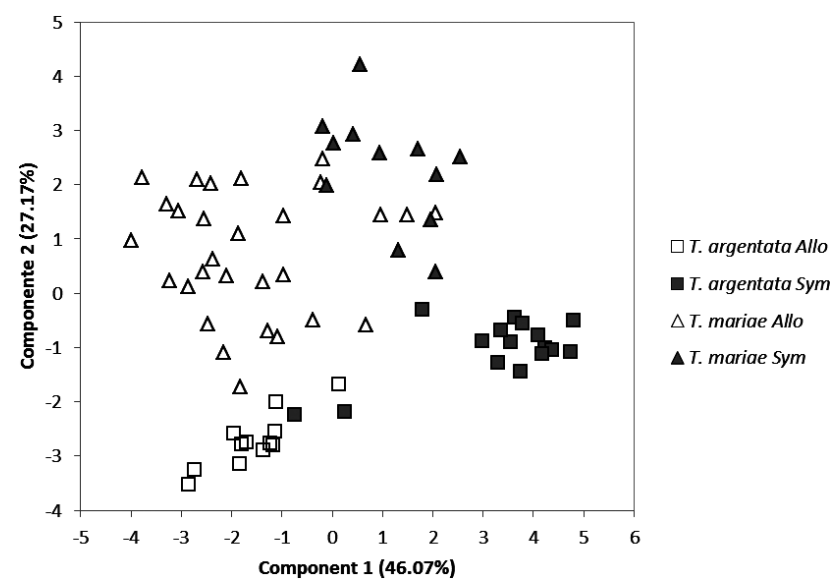

Fig. 6. Scatter plot of the 69 Tettigettalna argentata and Tettigettalna mariae occurring allopatrically (Allo) and sympatrically (Sym) in the first two PCA components extracted from a correlation matrix composed of 13 acoustic variables. See ST3 for details of the Eigen analysis and factor loadings.

nonparametric analysis showed that there is a significant difference between species in the scores of component $2(\mathrm{KW}, \mathrm{p}<0.0042)$ and no difference between allopatric and sympatric populations of the same species $(\mathrm{KW}$, $\mathrm{p}>0.0042$ ). Conversely, the sympatric populations of both species are distributed on the right side of the scatter plot, therefore separate from the allopatric populations separated by component 1 . Since component 1 is negatively correlated with most frequency variables (ST3), this distribution means that, in general, sympatric populations of both species have lower frequencies. KW analysis showed that the scores of component 1 differ between populations $(p<0.0042)$ but not between species $(p>0.0042)$.

The morphometric analysis revealed that populations of both species differ significantly. Specimens of Tettigettalna argentata differ in more morphometric traits, namely, BL; ML; ID, OW; TL; FL; aWW; aWL; RCL; pWW and pWL (Fig. 7A; MW, $\mathrm{p}<0.0023$ ). The values of all these traits are higher in the sympatric populations, indicating that individuals in these populations are generally larger and on average $2.89 \mathrm{~mm}$ bigger than their allopatric conspecifics.

The sympatric populations of T. mariae also have higher values for several morphometric traits. However, differences between the populations of this species are smaller than those of $T$. argentata, with only four significantly different traits, ML; OW; pWW and PCL (Fig. 7B; MW, $\mathrm{p}<0.0023)$.

A total of three components were extracted by the PCA, which account for $67.41 \%$ of the variation (ST4). The scatter plot of the first two principal components (Fig. 8) did not separate the species, but reveals that the allopatric and sympatric populations differ. The sympatric populations are in a grouping below and to the right of the allopatric populations, indicating that individuals in sympatric populations are generally larger. The KW nonparametric test revealed significant differences between sympatric and allopatric populations of T. argentata in terms of component 1 (KW, $\mathrm{p}<0.0042)$. Component 2 also revealed significant differences between the allopatric populations of $T$. mariae and the sympatric populations of both species and also between the sympatric populations of T. argentata and allopatric populations of T. mariae $(\mathrm{KW}, \mathrm{p}<0.0042)$.

\section{DISCUSSION}

The calling songs of the four Tettigettalna species analysed, can in general be distinguished by the human ear and so far are the best diagnostic character for identifying and distinguishing these species in the field. The interspecific analysis of these songs seems to indicate that time variables are species-specific and our results agree with those of previous studies (e.g. Boulard \& Quartau, 1991; Fonseca, 1991; Quartau et al., 1999). Both T. josei and T. estrellae can be unmistakably identified by their calling songs: that of T. estrellae is composed of long elements while that of $T$. josei of long phrases. Our results for T. argentata differ slightly from those reported in Quartau et al. (1999): the upper limit of the frequency range in our dataset is $17 \mathrm{kHz}$ instead of $15 \mathrm{kHz}$. For T. mariae, our results are dissimilar from those previously reported. In the frequency domain, Fonseca (1991) indicates that T. mariae has a broad spectrum with maximum energy around $13.5-14 \mathrm{kHz}$, while our results indicate a maximum energy between $7-14 \mathrm{kHz}$. The difference is not large and probably reflects the greater intraspecific variation expected from our larger sample size.

The results of the morphometric analysis are in general agreement with those of previous studies (e.g. Boulard, 1982; Boulard \& Quartau, 1991; Quartau \& Boulard, 1995). However, they showed low interspecific variability and did not allow a complete separation of all the species studied.

Except for $T$. josei, which is easily distinguished by its smaller size, the other three species are morphologically very similar. No single or set of morphometric traits analyzed proved suitable for identifying the three larger species. It is possible that the incorporation of geometric morphometry in the analysis (e.g. Yee et al., 2009) or the analysis of ratios (Baur \& Leuenberger, 2011) may be more informative.

The interspecific analysis revealed that the closest pair of species is T. argentata and T. mariae. The time domains of the songs of $T$. mariae and $T$. argentata differ significantly and in general distinctly differ to the human ear.

However, there is an overlap between the maximum and minimum values of all variables except for the number of echemes/s, with values between 10-17 for T. argentata and 2-9 for T. mariae. Therefore, specimens of T. argentata with values at the lower limit of its range could be mistakenly identified in the field as T. mariae and vice-versa. However, when only the sympatric populations of each species are compared, overlap occurs only in the echeme duration and echeme/inter-echeme interval. Therefore the structure of the time domain of the calling song of these two species may be sufficiently different to allow females to recognize conspecific males, both in allopatry and sympatry. However, it is still uncertain and important to per- 

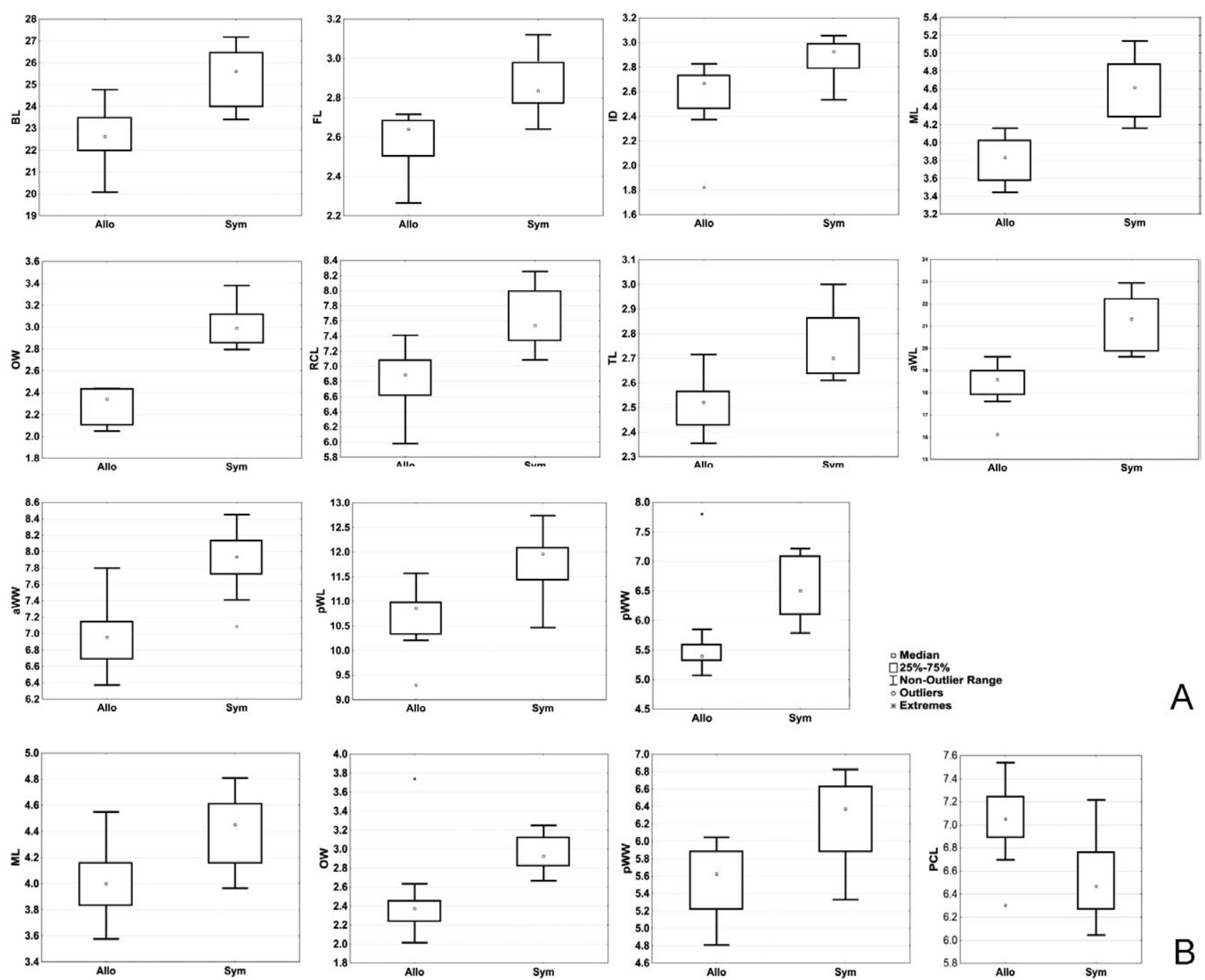

Fig. 7. Box plot of the morphometric traits that differed statistically (Mann-Whitney, $p<0.0039$ ) between allopatric (Allo) and sympatric (Sym) populations of A - Tettigettalna argentata and B - Tettigettalna mariae. All measurements are in millimetres. See Table 2 for description of the morphometric traits.

form playback experiments with both species and analyse how females respond to conspecific and allospecific males, as well as carrying out a more detailed search for critical acoustic parameters and tests on the thresholds of the responses of females and males to conspecific and allospecific calls.

In contrast, the differences found in the frequency domain in allopatric and sympatric populations of both $T$. argentata and T. mariae are intriguing. When the distributions of two closely related species overlap, a divergence would be expected in sympatric populations (character displacement) (Dobzhansky, 1937), which would decrease competition or reduce hybridization (Wasserman et al., 1977). However, this does not seem to be the case. The divergence between allopatric and sympatric populations of the same species does not correspond to a greater divergence between sympatric populations of the two species, which is contrary to what is expected in species undergoing character displacement.

As already referred to, cicadas are often gregarious (e.g. Sueur, 2002; Quartau \& Simões, 2003) and their calling signals have the dual role of attracting females at long range and attracting conspecific males, which aggregate and produce choruses (Alexander, 1968). Previous studies on Tibicina haematodes (Scopoli, 1763) have shown that males of this species respond to the call of other conspecific males (Sueur \& Aubin 2002). Males stop responding when the signal is shifted down or up by $2000 \mathrm{~Hz}$ and no response is observed when the sound broadcast is completely outside the limits of their own frequency production. However, males respond to the song of an allospecific with a completely distinct temporal pattern but produced at frequencies matching those of $T$. haematodes (Sueur \& Aubin, 2002). Since there is the potential of acoustic interference in multispecies populations (Sueur \& Aubin 2002; Sueur, 2003), this suggests that males of $T$. mariae and $T$. argentata, producing similar frequencies, might also respond to one another and misidentify allospecific males as competitors.

In dense aggregations, calling individuals tend to either alternate or synchronize their calling signals with neighbouring males. The cause of this signalling interaction 


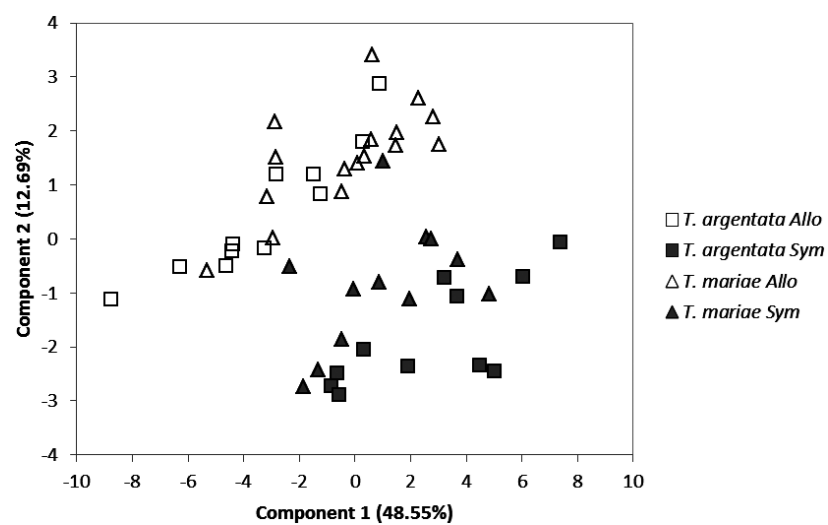

Fig. 8. Scatter plot of the 50 Tettigettalna argentata and Tettigettalna mariae occurring allopatrically (Allo) and sympatrically (Sym) in the first two PCA components extracted from a correlation matrix composed of measurements of 22 morphometric traits. See ST4 for details of the Eigen analysis and factor loadings.

between males is not fully understood, but is either cooperation or the outcome of competing males jamming each other's signal (Greenfield, 1994a, b). During the fieldwork at sympatric locations, we observed that males of both species tended to have a patchy distribution, with groups of 5 to 15 males singing in chorus with their conspecifics. Males singing in high pine trees tended to be static, singing for hours at the same calling site, whereas males singing in shrubs or small trees $(<3 \mathrm{~m}$ high) moved more often. As a result the same trees were often used by males of both species but only occasionally were they found in syntopy and singing simultaneously on the same tree.

Under these conditions, where competition for acoustic space is fierce, it may be advantageous to produce lower frequency songs since sound propagation in air is frequency-dependent, with greater attenuation of high frequencies (Naguib \& Wiley, 2001). This could explain the downshift in frequency recorded for males in sympatric populations of both T. argentata and T. mariae.

We also found that the body size in sympatric populations of both $T$. argentata and T. mariae was larger. The reason for this difference is unclear, but it may also be related to interspecific male-male competition. Aggressive behaviour between males has not yet been described for this genus and there are only a few such reports for species of cicada. Cocroft \& Pogue (1996) describes rivalry behaviour between the males of the cicada Fidicina mannifera. When the distance between neighbouring males decreases, males switch from songs to calls (rivalry signal). Bouts of calls of two males, which are apparently involved in a dispute over a calling site, are usually followed by the males walking parallel to one another. Similar behaviour is reported by Sueur (2003) between conspecific males in three species of Tibicina. When a silent and mobile male, approaches a singing static male, one or both males produce a jerking song (direct acoustic aggression). If this interaction does not result in one of the male's withdrawing, then the insects may escalate the interaction by making body contact and engaging in rapid grappling and kicking movements.

In both reports, competition between males seems to be primarily resolved by the rivals singing in opposition rather than by direct physical aggression; however they resort to the latter if the former is insufficient. In these situations the bigger individual may be at an advantage since it is more likely that large males will be able to maintain a dominant status [see Serrano-Meneses et al. (2007) for an example with damselflies and Alcock $(1995,1996)$ with bees]. This behaviour seems to be related to territory protection as it is more likely to occur in places where the density of males is high, as was the case at the locations with sympatry sampled in this study. In high density populations, $T$. argentata and $T$. mariae males may not recognise each other as allospecifics, which may account for their larger body size as a by-product of intra- and interspecific male-male competition. On the other hand, as there is a negative correlation between body length and the dominant song frequency (Bennet-Clark \& Young, 1994), it is unclear if the decrease in frequency is a by-product of the larger body size (e.g. Podos, 2001), or, vice versa (Jang et al., 2009). Either way, the shifts in frequency and body size in T. argentata and $T$. mariae may not give them a competitive advantage when both species "choose" the same strategy.

Finally, our results support the idea that the structure of the time domain of the calling song of the species studied seems to be sufficiently different for the recognition of conspecific males and account for reproductive isolation, both in allopatry and sympatry. Whether females perceive the acoustic signals in the same way as males remains to be determined.

ACKNOWLEDGEMENTS. This study was financially supported by project PTDC/BIA-BIC/115511/2009 of the Portuguese Foundation for Science and Technology (FCT). We thank B. Novais and E. Marabuto for their help with the field work. We thank four anonymous reviewers for their useful comments, which helped to improve the manuscript.

\section{REFERENCES}

Adams D.C. \& RohlF F.J. 2000: Ecological character displacement in Plethodon: biomechanical differences found from a geometric morphometric study. - Proc. Natl. Acad. Sci. USA 97: 4106-4111.

Alcock J. 1995: Body size and its effect on male-male competition in Hylaeus alcyoneus (Hymenoptera: Colletidae). $-J$. Insect. Behav. 8: 149-159.

Alcock J. 1996: The relation between male body size, fighting and mating success in Dawson's burrowing bee, Amegilla dawsoni (Apidae, Apinae, Anthophorini). - J. Zool. (Lond.) 239: 663-674.

AleXANDER R.D. 1968: Arthropods. In Sebeok T.E. (eds): Animal Communication: Techniques of Study and Results of Research. Indiana University Press, London, pp. 167-216.

BAur H. \& LeuenBerger C. 2011: Analysis of ratios in multivariate morphometry. - Syst. Biol. 60: 813-825.

Bennet-Clark H. \& Young D. 1994: The scaling of song frequency in cicadas. - J. Exp. Biol. 191: 291-294. 
Boulard M. 1982: Les cigales du Portugal, contribution à leur étude [Hom. Cicadidae]. — Annls. Soc. Entomol. Fr. 18: 181198.

Boulard M. 2006: Acoustic signals, diversity and behaviour of cicadas (Cicadidae, Hemiptera). In Drosopoulos S. \& Claridge M.F. (eds): Insect Sounds and Communication: Physiology, Behaviour, Ecology, and Evolution. Taylor \& Francis, New York, pp. 331-349.

Boulard M. \& Quartau J. 1991: Tettigetta septempulsata, nouvelle cigale lusitanienne (Homoptera, Cicadoidea, Tibicinidae). - EPHE Trav. Lab. Biol. Evol. Ins. 4: 49-56.

Cocroft R.B. \& Pogue M. 1996: Social behavior and communication in the neotropical cicada Fidicina mannifera (Fabricius) (Homoptera: Cicadidae). J. Kans. Entomol. Soc. 69: 85-97.

Cooley J. \& Marshall D. 2001: Sexual signaling in periodical cicadas, Magicicada spp. (Hemiptera: Cicadidae). - Behaviour 138: 827-855.

Dobzhansky T.T. 1937: Genetics and the Origin of Species. Columbia University Press, New York.

D’Urso V. 1995: Homoptera Auchenorrhyncha. In Minelli L., Rufo A. \& La Posta S. (eds): Checklist delle Specie della Fauna Italiana. Vol. 42. Calderini, Bologna, pp. 1-35.

Dyтнам C. 2011: Choosing and Using Statistics: A Biologist's Guide. 3rd ed. Wiley-Blackwell, Oxford, 298 pp.

FONSECA P. 1991: Characteristics of the acoustica signals in nine species of cicadas (Homoptera, Cicadidae). - Bioacoustics $\mathbf{3}$ : 173-192.

Gogala M. 2002: Gesänge der Singzikaden aus Südost- und Mittel-Europa. In Holzinger W.E. (ed.): Zikaden: Leafhoppers, Planthoppers and Cicadas (Insecta: Hemiptera: Auchenorrhyncha). (Denisia, 4), (Kataloge des O. Landesmuseums, Neue Folge, 176). Biologiezentrum des O. Landesmuseums, Linz, pp. 241-248.

Gogala M. \& Gogala A. 1999: A checklist and provisionals atlas of the cicadoidea fauna of Slovenia (Homoptera: Auchenorryncha). - Acta Entomol. Sloven. 7: 119-128.

GREenFIELD M.D. 1994a: Synchronous and alternating choruses in insects and anurans: Common mechanisms and diverse functions. - Am. Zool. 34: 605-615.

GreENFIELD M.D. 1994b: Cooperation and conflict in the evolution of signal interactions. Annu. Rev. Ecol. Syst. 25: 97-126.

GreENFIELd M.D. \& SNedden W.A. 2002: Selective attention and the spatio-temporal structure of orthoperan choruses. $-B e-$ haviour 140: 1-26.

Grether G.F., Losin N., Anderson C.N. \& OKamoto K. 2009: The role of interspecific interference competition in character displacement and the evolution of competitor recognition. Biol. Rev. 84: 617-635.

Hertach T. 2008: A new cicada species for Switzerland: Tettigetta argentata (Olivier, 1790) (Hemiptera: Cicadoidea). — Bull. Soc. Entomol. Suisse 81[2007]: 209-214.

Jang Y., Won Y. \& Choe J. 2009: Divergent patterns of morphological differentiation provide more evidence for reproductive character displacement in a wood cricket Gryllus fultoni (Orthoptera: Gryllidae). - BMC Evol. Biol. 9(27).

Marshall C.D. \& Cooley J. 2000: Reproductive character displacement and speciation in periodical cicadas, with description of a new species, 13-year magicicada neotredecim. Evolution 54: 1313-1325.

MAYr E. 1963: Animal Species and Evolution. Belknap Press of Harvard University Press, Cambridge, MA, 797 pp.

NAGUIB M. \& WiLEY R.H. 2001: Estimating the distance to a source of sound: mechanisms and adaptations for long-range communication. - Anim. Behav. 62: 825-837.
Nunes V.L., Mendes R., Marabuto E., Novais B.M., Hertach T., Quartau J.A., Seabra S.G., Paulo O.S. \& Simões P.C. 2014; Conflicting patterns of DNA barcoding and taxonomy in the cicada genus Tettigettalna from southern Europe (Hemiptera: Cicadidae). - Mol. Ecol. Res. 14: 27-38.

PAterson H.E.H. 1985: The recognition concept of species. In Vrba E.S. (eds): Species and Speciation. Transvaal Museum Monograph 4, Pretoria, pp. 21-29.

Pinto-Juma G., Simões P., Seabra S. \& Quartau J. 2005: Calling song structure and geographic variation in Cicada orni Linnaeus (Hemiptera: Cicadidae). — Zool. Stud. 44: 81-94.

PoDos J. 2001: Correlated evolution of morphology and vocal signal structure in Darwin's finches. Nature 409: 185-188.

Puissant S. \& Sueur J. 2010: A hotspot for Mediterranean cicadas (Insecta: Hemiptera: Cicadidae): new genera, species and songs from southern Spain. - Syst. Biodiv. 8: 555-574.

Quartau J. \& Boulard M. 1995: Tettigetta mariae n. sp., nouvelle cigale lusitanienne (Homoptera, Cicadoidea, Tibicinidae). - EPHE Trav. Lab. Biol. Evol. Ins. 7-8: 105-110.

QuARTAU J. \& SiMÕes P. 2003: Bioacoustic and morphological differentiation in two allopatric species of the genus Tibicina Amyot (Hemiptera, Cacadoidea) in Portugal. - Mitt. Mus. Nat.kd. Berl., Dtsch. Entomol. Z. 50: 113-119.

Quartau J. \& Simões P. 2006: Acoustic evolutionary divergence in cicadas: The species of Cicada L. in Southern Europe. In Drosopoulos S. \& Claridge M.F. (eds): Insect Sounds and Communication: Physiology, Behaviour, Ecology, and Evolution. Taylor \& Francis, Boca Raton, pp. 227-237.

Quartau J.A., Rebelo M.T. \& Simões P.C. 1999: Cicadídeos (Insectos, Homópteros). In Santos-Reis M. \& Correia A.I. (eds): Caracterização da flora e da fauna do montado da Herdade da Ribeira Abaixo (Grândola - Baixo Alentejo). Centro de Biologia Ambiental, Lisboa, pp. 69-74.

SCHEDL W. 1986: Zur Verbreitung, Biologie und Okologie der Singzikaden von Istrien und dem angrenzendem Kustenland (Homoptera: Cicadidae and Tibicinidae). - Zool. Jb. Syst. 113: $1-17$.

Seabra S., Pinto-Juma G. \& Quartau J. 2006: Calling songs of sympatric and allopatric populations of Cicada barbara and $C$. orni (Hemiptera: Cicadidae) on the Iberian Peninsula. — Eur. J. Entomol. 103: 843-852.

Serrano-Meneses M.A., Córdoba-Aguilar A., Méndez V., Layen S.J. \& Szekely T. 2007: Sexual size dimorphism in the American rubyspot: male body size predicts male competition and mating success. - Anim. Behav. 73: 987-997.

Snedden A., Greenfiels M.D. \& JANG Y. 1998: Mechanisms of selective attention in grasshopper choruses: who listens to whom? - Behav. Ecol. Sociobiol. 43: 59-66.

SueUR J. 2002: Cicada acoustic communication: potential sound partitioning in a multispecies community from Mexico (Hemiptera: Cicadomorpha: Cicadidae). - Biol. J. Linn. Soc. 75: 379-394.

SuEUR J. 2003: Indirect and direct acoustic aggression in cicadas: first observations in the Palaearctic genus Tibicina Amyot (Hemiptera: Cicadomorpha: Cicadidae). — J. Nat. Hist. 37: 2931-2948.

Sueur J. \& Aubin T. 2002: Acoustic communication in the Palaearctic red cicada, Tibicina haematodes: chorus organisation, calling-song structure, and signal recognition. - Can. J. Zool. 80: $126-136$.

Sueur J., Puissant S., Simões P.C., Seabra S., Boulard M. \& QuARTAU J.A. 2004: Cicadas from Portugal: revised list of species with eco-ethological data (Hemiptera: Cicadidae). - Insect Syst. Evol. 35: 177-187. 
Wasserman M., Koepfer R.H. \& Koepfer H. 1977: Character displacement for sexual isolation between Drosophila mojavensis and Drosophila arizonensis. - Evolution 31: 812-823.

Yee W.L., Chapman P.S., Sheets H.D. \& Unruh T.R. 2009: Analysis of body measurements and wing shape to discriminate Rhagoletis pomonella and Rhagoletis zephyria (Diptera: Tephritidae) in Washington state. - Ann. Entomol. Soc. Am. 102: $1013-1028$

Received July 15, 2013; revised and accepted February 4, 2014 Prepublished online June 17, 2014

SuPPLEMENT 1. Eigen analysis and Factor loadings of a principal component analysis (PCA) of a correlation matrix of 13 acoustic variables of 193 specimens of Tettigettalna. Numbers in bold correspond to absolute loading values equal to or greater than 0.6.

\begin{tabular}{lrrr}
\hline & PCA 1 & PCA 2 & PCA 3 \\
\hline \multicolumn{1}{c}{ EIGEN ANALYSIS } & & & \\
Eigenvalues & 6.026 & 4.261 & 1.522 \\
Total variance (\%) & 46.35 & 32.78 & 11.71 \\
Cumulative variance (\%) & 46.35 & 79.13 & 90.84 \\
\hline \multicolumn{1}{c}{ ComPONENT LOADING PER VARIABLE } & & & \\
No. of echemes/s & $\mathbf{0 . 8 5 2}$ & 0.218 & 0.023 \\
Echeme duration (s) & -0.244 & $-\mathbf{0 . 9 2 4}$ & 0.248 \\
Inter-echeme interval (s) & -0.364 & $-\mathbf{0 . 8 3 4}$ & 0.270 \\
Echeme period (s) & -0.308 & $-\mathbf{0 . 9 0 9}$ & 0.266 \\
Echeme/inter-echeme interval ratio & -0.192 & $-\mathbf{0 . 8 8 7}$ & 0.254 \\
Peak frequency (Hz) & $\mathbf{0 . 8 7 9}$ & -0.266 & -0.032 \\
Minimum frequency (Hz) & $\mathbf{0 . 8 5 8}$ & -0.384 & -0.156 \\
Maximum frequency (Hz) & $\mathbf{0 . 8 2 9}$ & 0.145 & 0.493 \\
Band width (Hz) & -0.104 & $\mathbf{0 . 6 0 1}$ & $\mathbf{0 . 7 0 6}$ \\
25\% Quartile (Hz) & $\mathbf{0 . 9 2 3}$ & -0.319 & -0.095 \\
50\% Quartile (Hz) & $\mathbf{0 . 9 6 2}$ & -0.168 & 0.117 \\
75\% Quartile (Hz) & $\mathbf{0 . 9 2 2}$ & 0.010 & 0.323 \\
75\% Quartile - 25\% Quartile (Hz) & -0.378 & 0.566 & 0.598 \\
\hline
\end{tabular}

SuPPLEMENT 2. Eigen analysis and Factor loadings of a principal component analysis (PCA) of a correlation matrix of 22 morphometric variables of 176 specimens of Tettigettalna. Numbers in bold correspond to absolute loading values equal to or greater than 0.6.

\begin{tabular}{|c|c|c|}
\hline & PCA 1 & PCA 2 \\
\hline \multicolumn{3}{|l|}{ EIGEN ANALYSIS } \\
\hline Eigenvalues & 14.40 & 1.94 \\
\hline Total variance $(\%)$ & 65.44 & 8.84 \\
\hline Cumulative variance (\%) & 65.44 & 74.27 \\
\hline \multicolumn{3}{|c|}{ COMPONENT LOADING PER VARIABLE } \\
\hline BL & 0.979 & -0.071 \\
\hline HL & 0.405 & 0.533 \\
\hline ML & 0.784 & -0.344 \\
\hline HW & 0.964 & -0.026 \\
\hline ID & 0.907 & -0.101 \\
\hline aWL & 0.966 & -0.101 \\
\hline aWW & 0.884 & -0.079 \\
\hline pWL & 0.963 & 0.041 \\
\hline pWW & 0.867 & -0.286 \\
\hline RCL & 0.956 & -0.084 \\
\hline PCL & 0.860 & 0.331 \\
\hline OW & 0.574 & -0.683 \\
\hline OOD & 0.664 & -0.201 \\
\hline PL & 0.906 & 0.182 \\
\hline CL & 0.820 & -0.038 \\
\hline $\mathrm{M}+\mathrm{Cu} 1 \mathrm{~L}$ & 0.391 & -0.093 \\
\hline BCL & 0.640 & 0.478 \\
\hline FL & 0.948 & -0.053 \\
\hline fTL & 0.726 & 0.353 \\
\hline TTD & 0.840 & 0.340 \\
\hline TL & 0.947 & 0.022 \\
\hline nTR & 0.059 & 0.536 \\
\hline
\end{tabular}

SuPPLEMENT 3. Eigen analysis and Factor loadings of a principal component analysis (PCA) of a correlation matrix of 13 acoustic variables of 69 specimens of T. mariae and T. argentata. Numbers in bold correspond to absolute component loadings equal to or greater than 0.6 .

\begin{tabular}{lrrr}
\hline & PCA 1 & PCA 2 & PCA 3 \\
\hline \multicolumn{1}{c}{ EIGEN ANALYSIS } & & & \\
Eigenvalues & 5.988 & 3.532 & 1.777 \\
Total variance (\%) & 46.07 & 27.17 & 13.67 \\
Cumulative variance (\%) & 46.07 & 73.24 & 86.91 \\
\hline \multicolumn{1}{c}{ ComPONENT LOADING PER VARIABLE } & & & \\
No. of echemes /s & 0.333 & $\mathbf{- 0 . 8 6 5}$ & 0.149 \\
Echeme duration (s) & -0.293 & $\mathbf{0 . 8 6 8}$ & -0.207 \\
Inter-echeme interval (s) & -0.501 & $\mathbf{0 . 8 2 4}$ & -0.169 \\
Echeme period (s) & -0.476 & $\mathbf{0 . 8 5 2}$ & -0.180 \\
Echeme/inter-echeme interval ratio & $\mathbf{0 . 6 4 6}$ & 0.115 & -0.143 \\
Peak frequency (Hz) & $\mathbf{- 0 . 8 4 2}$ & -0.339 & -0.189 \\
Minimum frequency (Hz) & $\mathbf{- 0 . 8 2 4}$ & -0.342 & -0.316 \\
Maximum frequency (Hz) & $\mathbf{- 0 . 7 8 1}$ & 0.019 & 0.582 \\
Bandwidth (Hz) & -0.310 & 0.259 & $\mathbf{0 . 8 7 0}$ \\
25\% Quartile (Hz) & $\mathbf{- 0 . 9 1 2}$ & -0.338 & -0.168 \\
50\% Quartile (Hz) & $\mathbf{- 0 . 9 2 9}$ & -0.216 & 0.052 \\
75\% Quartile (Hz) & $\mathbf{- 0 . 8 0 6}$ & -0.053 & 0.381 \\
75\% Quartile - 25\% Quartile (Hz) & $\mathbf{0 . 6 7 7}$ & 0.387 & 0.473 \\
\hline
\end{tabular}


SuPPLEMENT 4. Eigen analysis and Factor loadings of a principal component analysis (PCA) of a correlation matrix of 22 morphometric variables of 50 specimens of $T$. mariae and T. argentata. Numbers in bold correspond to absolute component loadings equal to or greater than 0.6 .

\begin{tabular}{|c|c|c|c|}
\hline & PCA 1 & PCA 2 & PCA 3 \\
\hline \multicolumn{4}{|l|}{ EIGEN ANALYSIS } \\
\hline Eigenvalues & 10.681 & 2.792 & 1.357 \\
\hline Total variance $(\%)$ & 48.55 & 12.69 & 6.17 \\
\hline Cumulative variance $(\%)$ & 48.55 & 61.24 & 67.41 \\
\hline \multicolumn{4}{|c|}{ COMPONENT LOADING PER VARIABLE } \\
\hline $\mathrm{BL}$ & 0.973 & 0.006 & 0.073 \\
\hline HL & -0.137 & 0.494 & 0.497 \\
\hline ML & 0.862 & -0.330 & -0.200 \\
\hline HW & 0.916 & 0.108 & 0.052 \\
\hline ID & 0.767 & -0.004 & 0.107 \\
\hline $\mathrm{aWL}$ & 0.936 & -0.179 & -0.074 \\
\hline aWW & 0.892 & -0.113 & -0.141 \\
\hline pWL & 0.888 & 0.025 & -0.078 \\
\hline pWW & 0.695 & -0.269 & -0.033 \\
\hline RCL & 0.919 & -0.066 & 0.053 \\
\hline PCL & 0.418 & 0.625 & -0.213 \\
\hline OW & 0.719 & -0.412 & 0.074 \\
\hline OOD & 0.449 & -0.109 & 0.123 \\
\hline PL & 0.653 & 0.405 & 0.275 \\
\hline CL & 0.662 & 0.268 & 0.268 \\
\hline $\mathrm{M}+\mathrm{Cu} 1 \mathrm{~L}$ & 0.099 & 0.184 & 0.648 \\
\hline BCL & 0.431 & 0.484 & -0.020 \\
\hline FL & 0.914 & -0.120 & -0.049 \\
\hline $\mathrm{fFL}$ & 0.119 & 0.678 & -0.340 \\
\hline TTD & 0.300 & 0.733 & -0.014 \\
\hline TL & 0.927 & -0.008 & -0.100 \\
\hline nTR & -0.056 & 0.465 & -0.503 \\
\hline
\end{tabular}

